\title{
Natalia Marzia Gusmerotti, Marco Frey e Fabio Iraldo Management dell'economia circolare. Principi, drivers, modelli di business e misurazione
}

Franco Angeli, Milano, 2020

Oggi più che mai il tema dell'Economia Circolare (EC) risulta fondamentale per affrontare le sfide del Green Deal Europeo (Commissione Europea, 2019), sviluppando nuovi approcci sostenibili capaci di incidere positivamente sul cambiamento dei modelli tradizionali di produzione e consumo ed in grado di condurci verso i paradigmi che la transizione ecologica ci impone.

La chiave di lettura che meglio ci consente di interpretare tale trasformazione è contenuta nei piani d'azione comunitari dedicati al tema dell'EC (Commissione Europea, 2015; 2020) e può essere riassunta come segue: dato lo sforzo che viene compiuto per estrarre risorse dalla natura e per trasformarle in prodotti o servizi dotati di valore economico, non ha alcun senso utilizzarle solo una volta, o comunque farne un uso limitato nel tempo, ma occorre usarle più volte possibile in cicli chiusi, riducendo così la pressione sulle materie prime vergini e limitando l'impatto ambientale dell'azione umana. L'obiettivo è quello, ispirandosi a modelli e sistemi di matrice organica e ambientale, di dare origine a flussi naturali di materia finalizzati a realizzare cicli produttivi ad elevato valore e di notevole qualità, attraverso la minimizzazione degli scarti e dell'inquinamento, grazie al design consapevole di prodotti, processi e servizi, ed in cui il valore delle risorse è mantenuto il più a lungo possibile e i sistemi naturali sono rigenerati. E, quindi, evidente come loriginalità del concetto di EC, che trae

Today, more than ever, the Circular Economy (CE) is fundamental in facing the challenges of the European Green Deal (European Commission, 2019) by developing new sustainable approaches capable of positively impacting the change in traditional production and consumption models and able to lead us towards the paradigms of the ecological transition.

The key to understanding and interpreting this transformation is contained in the community action plans dedicated to the CE theme (European Commission, 2015; 2020). It can be summarized as follows: given the effort that is made to extract raw materials from nature and to transform them into products or services with economic value, it makes no sense to use these materials only once, or in any case to make limited their use over time, but it is necessary to use them as many times as possible in closed cycles. Thus, reducing the pressure on virgin raw materials and limiting the overall environmental impact of human action.

The goal is, inspired by models and systems of an organic and environmental matrix, to create natural flows of matter aimed at achieving production cycles of high value and high quality, through the minimization of waste and pollution, thanks to the conscious design of products, processes, and services, and in which the value of resources is maintained as long as possible, and natural systems are regenerated.

Therefore, it is evident how the originality of the CE concept, which draws inspiration from the different business economy models - from environmental and ecological economics to industrial ecology, from cradle to ispirazione da diversi modelli di business economy - dalleconomia ambientale ed ecologica, allecologia industriale, per passare dal cradle to cradle, alla performance economy, alla Blue economy ed alla biomimicry - può avere un impatto molto significativo sui processi produttivi, inducendo le imprese più innovative a porsi in una prospettiva differente rispetto a tutte le fasi del ciclo di vita dei prodotti e dei servizi, a partire dall'approvvigionamento, passando dal design, dalla produzione, dalla distribuzione, dal consumo, e infine, dal recupero dei materiali che non divengono rifiuti, ma possono essere raccolti, riciclati e/o riutilizzati.

Il volume "Management delleconomia circolare. Principi, drivers, modelli di business e misurazione" parte proprio da questa considerazione per avviare una riflessione destinata a tutti gli attori del sistema (siano essi imprese, istituzioni, stakeholder o policy maker) che sono coinvolti direttamente e/o indirettamente nel processo epocale di trasformazione sociale, economica ed industriale in atto.

Lo scopo degli autori è quello di definire sia i principi e i criteri che devono guidare la transizione verso la massimizzazione della circolarità, quanto i driver - esterni ed interni - che dovranno stimolare le imprese al cambiamento, approfondendo la conoscenza dei nuovi modelli di business e degli strumenti di misurazione dei livelli di circolarità. Per raggiungere questi obiettivi il libro è strutturato in quattro capitoli, dedicati sia alla puntuale ricognizione del quadro teorico di riferimento, che alla presentazione dei risultati di alcuni progetti di ricerca sviluppati presso la Scuola Superiore Sant'Anna di Pisa dai docenti e dai ricercatori coinvolti nella pubblicazione.

La trattazione parte da unanalisi delle origini, dei principi e degli elementi prospettici del concetto di EC, effettuata connettendo cradle, performance economy, to Blue economy and biomimicry - can have a very significant impact on the contemporary production models. Indeed, the $\mathrm{CE}$ approach induces the most innovative companies to take a different perspective concerning all phases of the life cycle of products and services: from material supply to the design phase; from production to distribution; from consumption to recovery, recycling, and reuse of raw materials. The book "Management of the circular economy. Principles, drivers, business models, and measurement" starts from this consideration to create a reflection aimed at all the players of the system (e.g. companies, institutions, stakeholders, or policymakers) who are directly and/or indirectly involved in the epochal process of social, economic, and industrial transformation. Accordingly, the authors' purpose is to define both the principles and criteria that must guide the transition towards maximizing circularity and the drivers, external and internal, that should stimulate companies to change, deepening their knowledge of the new business models and tools for measuring the circularity levels. Therefore, the book is structured in four chapters, dedicated to recognizing the theoretical framework of reference and presenting some research projects developed at the Sant'Anna School of Advanced Studies in Pisa by the teachers and researchers involved in the publication. The book dissertation starts from the analysis of the origins, principles, and prospective elements of the $\mathrm{CE}$ concept, which was carried out by connecting the literature review with some research works, conducted together with the companies participating in projects aimed at identifying the key 
la rassegna della letteratura con un lavoro di comprensione e definizione, condotto insieme alle imprese partecipanti ad alcuni progetti finalizzati a identificare quelli che sono gli elementi chiave che dovrebbero caratterizzare un orientamento strategico alla circolarità. Si passa quindi alla presentazione del quadro delle politiche sull'EC che si sono sviluppate a livello internazionale e nazionale, connettendole con le dinamiche e le esigenze delle imprese e dei consumatori ed evidenziando i necessari e auspicabili processi di trasformazione futura. Vengono, inoltre, descritti i principali stakeholder per un'impresa interessata a rinnovarsi nell'ottica della circolarità e, per ciascuno di essi, sono fornite indicazioni e tendenze emergenti da diverse fonti di riferimento. La definizione dei circular oriented business model risulta, quindi, fondamentale a promuovere l'innovazione di processo e di prodotto al fine di presentare alcune esperienze aziendali particolarmente efficaci nell'attuare percorsi evolutivi verso l'EC, facendo riferimento a modelli di strategic management.

Nellottica della necessità di definire strumenti validi di misurazione della circolarità, capaci di stimolare le performances ambientali a livello di impresa, di settore e di sistema socioeconomico, gli autori definiscono, infine, una panoramica dei contributi metodologici e dei sistemi di indicatori esistenti, descrivendo successivamente nel dettaglio il tool di misurazione (CECUT), sviluppato in collaborazione con GEO (il Green Economy Observatory dell'Università Bocconi di Milano). Tale originale strumento può essere utilizzato per valutare il livello di partenza della circolarità nelle diverse fasi del processo di produzione di beni e servizi, fornendo un primo set di spunti capaci di far comprendere rapidamente quali impatti possono essere generati attraverso l'adozione di strategie circolari nel perimetro di una

elements that should characterize a strategic orientation to circularity. The analysis is followed by introducing the framework of the EC policies, which have been developed at an international and national level, connecting it with the dynamics and needs of businesses and consumers, and highlighting the necessary and desirable future transformation processes. Furthermore, for a company interested in renewing itself in the perspective of circularity, the main stakeholders are described and, for each of them, indications and trends emerging from various reference sources are provided. Then, the definition of circular-oriented business models is fundamental to promote process and product innovation to present some particularly effective business experiences in implementing evolutionary paths towards CE, referring to strategic management models. singola impresa, di una filiera, di un settore di mercato (come, ad esempio, quello delle costruzioni).

L'importanza e la strategicità dell'EC, la necessità di un contributo di stampo manageriale, l'approccio metodologico al tema (basato sul metodo dell'Action Research) rendono questo volume una proposta originale nel panorama editoriale nazionale, fruibile realmente da diverse tipologie di lettori, compresi gli architetti o i ricercatori dell'area tecnologica, che nei suoi contenuti possono trovare interessanti ed attuali spunti necessari ad avviare un pragmatico processo di revisione dei modelli metodologici di gestione del processo edilizio, fondati su una visione circolare di matrice ambientale ed ispirati all'approccio universale del $S y$ stem Thinking.

Rosa Romano

\section{REFERENCES}

Commissione Europea (2015), L'anello mancante - Piano d'azione dell'Unione europea per leconomia circolare, Comunicazione della Commissione al Parlamento Europeo, al Consiglio, al Comitato Economico e Sociale Europeo e al Comitato delle regioni, COM (2015) 614, Bruxelles, Belgium.

Commissione Europea (2019), Il Green Deal Europeo, Comunicazione della Commissione al Parlamento Europeo, al Consiglio, al Comitato Economico e Sociale Europeo e al Comitato delle regioni, COM (2019) 640, Bruxelles, Belgium.

Commissione Europea (2020), Un nuovo piano d'azione per l'economia circolare per un'Europa più pulita e più competitiva, Comunicazione della Commissione al Parlamento Europeo, al Consiglio, al Comitato Economico e Sociale Europeo e al Comitato delle Regioni, COM (2020) 98, Bruxelles, Belgium.

ture of the EC, the need for a managerial contribution, and the methodological approach to the topic (based on the Action Research method) make this book an original proposal in the national editorial panorama, truly valuable for different types of readers, including architects or researchers of the technological area. They can find in its contents interesting and innovative ideas necessary to start a pragmatic process of revising the methodological models for managing the building process, based on a circular vision of an environmental matrix, and inspired to the universal approach of System Thinking.

Rosa Romano 